\title{
Znamiona państwa wyznaniowego. Uwagi na kanwie dorobku współczesnego konstytucjonalizmu
}

\section{Wprowadzenie}

Analiza współcześnie obowiązujących konstytucji, szczególnie tych ustanowionych u schyłku XX w. oraz już w XXI stuleciu, prowadzi do wniosku, że ustrój państwa wyznaniowego stopniowo traci swą popularnośćn ${ }^{\text {. Nie }}$ można jednak mówić o jego powszechnym i szybkim zaniku. Religia wciąż ma dla rządzących istotne atuty. Jest często instrumentem legitymizacji władzy, czynnikiem integrującym społeczeństwa, szczególnie wieloetniczne, bądź źródłem norm stabilizujących życie indywidualne i kolektywne. Przy tym normatywny, zwłaszcza konstytucyjny, ustrój państwa wyznaniowego nie powinien być apriorycznie uznawany za sprzeczny ze standardami demokratycznymi oraz wolnościami i prawami człowieka ${ }^{2}$. Celem niniejszego opracowania jest ustalenie, czy we

${ }^{1}$ Na temat historycznych form państwa wyznaniowego zob.: A. Mezglewski, H. Misztal, P. Stanisz, Prawo wyznaniowe, Warszawa 2011, s. 12-16; J. Krukowski, Kościelne prawo publiczne. Prawo konkordatowe, Lublin 20013, s. 11-45; M. Pietrzak, Prawo wyznaniowe, Warszawa 2013, s. 56-66.

${ }^{2}$ Pośrednio analizowany system relacji między państwem a religią legitymizuje Unia Europejska. Traktat o funkcjonowaniu Unii Europejskiej w art. 17 ust. 1 i 2 stanowi bowiem: „1. Unia szanuje status przyznany na mocy prawa krajowego kościołom i stowarzyszeniom lub wspólnotom religijnym w Państwach Członkowskich i nie narusza tego statusu. 2. Unia szanuje również status organizacji światopoglądowych i niewyznaniowych przyznany im na mocy prawa krajowego". Także Konwencja o Ochronie Praw Człowieka i Podstawowych Wolności z 1950 r. w świetle orzecznictwa Europejskiego Trybunału Praw Człowieka nie zakazuje istnienia Kościoła państwowego stanowiącego element tradycji i tożsamości narodowej. Nie ma też zakazu, by pomoc i współdziałanie 
współczesnym konstytucjonalizmie jest możliwa rekonstrukcja normatywnych znamion państwa wyznaniowego. Ponadto na podstawie charakterystycznych cech państwa wyznaniowego wyrażonych w obecnie obowiązujących ustawach zasadniczych, ze szczególnym uwzględnieniem tych ustanowionych już w obecnym stuleciu, podjęta zostanie próba określenia szczegółowego modelu państwa wyznaniowego. Przedmiotem analizy będzie także miejsce klauzul wyznaniowych w systematyce aktów konstytucyjnych. Kolejnym zamierzonym elementem rozważań jest wskazanie najbardziej charakterystycznych sformułowań. Można zaryzykować przypuszczenie, że sformułowanie szczegółowego modelu państwa wyznaniowego na podstawie samych tylko ustaw zasadniczych będzie trudne ze względu na sam charakter przepisów ustrojowych. W kontekście wskazanych powyżej zagadnień podjęto ponadto próbę odpowiedzi na jeszcze jedno istotne pytanie: Czy ustrój państwa wyznaniowego jest do pogodzenia z wolnością w sprawach religijnych?

\section{Państwa wyznaniowe - główne kierunki przemian we współczesnym świecie}

Państwo wyznaniowe staje się stopniowo zjawiskiem charakterystycznym przede wszystkim dla krajów związanych socjologicznie i kulturowo z religią muzułmańską. Są to zwłaszcza państwa Afryki Północnej, Bliskiego i Środkowego Wschodu oraz Indonezja. Ustrój państwa konfesyjnego w wymiarze ustrojowym uległ natomiast ograniczeniu w krajach znajdujących się w kręgu oddziaływania chrześcijaństwa, szczególnie katolicyzmu ${ }^{3}$, w mniejszym stopniu - protestanty-

państwa dla najsilniej ustabilizowanych Kościołów były wyraźniejsze niż wobec nowo powstałych i nieznanych grup wyznaniowych. Zob. Konwencja o Ochronie Praw Człowieka i Podstawowych Wolności, t. 1: Komentarz do artykułów 1-18, pod red. L. Garlickiego, Warszawa 2010, s. 560, 579; M. Hucał, Wolność sumienia i wyznania w orzecznictwie Europejskiego Trybunału Praw Człowieka, Warszawa 2012, s. 94-96.

${ }^{3}$ Zasadniczej zmiany w dziedzinie koncepcji relacji między państwem a Kościołem dokonał Kościół katolicki podczas Soboru Watykańskiego II (lata: 1962-1965) oraz w nauczaniu papieży posoborowych, m.in. Pawła VI i Jana Pawła II. Uznał zwłaszcza za zgodną z doktryną katolicką zasadę „zdrowej” świeckości państwa oraz wolność w sprawach religijnych (libertas in re religiosa). Zob. szerzej P. Sobczyk, Kościół a wspólnoty polityczne, Warszawa 2005. We współczesnej Europie państwami katolickimi w świetle konstytucji pozostały w większości nieliczne i niewielkie terytorialnie podmioty: Andora, Malta, Lichtenstein, Monako, Państwo Watykańskie oraz Irlandia. W 1976 r. bezpośrednio w swojej konstytucji (art. 41 ust. 4) zasadę oddzielenia związków wyznaniowych 
$z^{4} u^{4}$. Wskazują na to przemiany prawne $w$ wielu państwach europejskich oraz latynoamerykańskich ${ }^{5}$. Nieliczna jest, zlokalizowana w Azji, grupa państw, w których konfesją oficjalną bądź uprzywilejowaną jest buddyzm. W świetle odpowiednich konstytucji można do nich zaliczyć jedynie Tajlandię $e^{6}$, Sri Lankę Kambodżę i Bhutan $^{8}$.

Po roku 1989, w związku przede wszystkim z kryzysem i rozpadem Związku Socjalistycznych Republik Radzieckich ${ }^{9}$ oraz jego strefy wpływów, zdecydowanemu ograniczeniu uległa grupa państw wyznaniowych à rebours, tzn. tych, w których miejsce oficjalnej religii zajmowała ideologia komunistyczna ${ }^{10}$. Współcześnie występują pojedyncze przypadki świeckich państw ideologicznych ${ }^{11}$. Są to: Chińska Republika Ludowa, Koreańska Republika Ludowo-Demokratyczna, Republika Kuby czy Socjalistyczna Republika Wietnamu. Ideologia komunistyczna bądź maoistowska straciła jednak definitywnie swój ekspansjonistyczny charakter. Zasadne jest przypuszczenie, że grupa państw ideologicznych będzie ulegała dalszej redukcji.

od państwa ustanowiła Portugalia; w 1978 r. w konstytucji Hiszpanii (art. 16 ust. 3) ustanowiono system rozdziału państwa i Kościoła, deklarując, że żadne wyznanie nie ma charakteru państwowego; natomiast w 1984 r., w wyniku derogacji zasady zawartej w konkordacie laterańskim, że katolicyzm jest jedyną religią państwa, państwem wyznaniowym przestały być Włochy.

${ }^{4}$ Od 2000 r. Kościół Ewangelicko-Luterański stracił status państwowego wyznania w Szwecji. Od 2017 r. Kościół Ewangelicko-Luterański przestał być Kościołem państwowym w Norwegii.

${ }^{5}$ Zob. W. Bar, Kwestie wyznaniowe w konstytucjach krajów Ameryki Łacińskiej i Karaibów, w: Prawo wyznaniowe w systemie prawa polskiego, pod red. A. Mezglewskiego, Lublin 2004, s. $152-155$.

${ }^{6}$ Zob. Konstytucja Królestwa Tajlandii z 2017 r. (sekcja 7) - http://www.constitu tionnet.org/sites/default/files/2017-05/CONSTITUTION\%2BOF\%2BTHE\%2BKING DOM\%2BOF\%2BTHAILAND\%2B\%28B.E.\%2B2560\%2B\%282017\%29\%29.pdf (dostęp: 5 XI 2017).

${ }^{7}$ Zob. art. 9 Konstytucji Demokratycznej Socjalistycznej Republiki Sri Lanki z 1978 r. - http://srilankalaw.lk/constitution-of-the-democratic-socialist-republic-of-sri-lanka.html (dostęp: 14 IX 2017).

${ }^{8}$ Zob. Konstytucja Królestwa Bhutanu z 2008 r. (art. 2 ust. 2 i art. 3) - https://www. constituteproject.org/constitution/Bhutan_2008.pdf?lang=en (dostęp: 14 IX 2017).

${ }^{9}$ ZSRR przestał istnieć w wyniku porozumienia białowieskiego z 8 XII 1991 r., zawartego przez prezydentów Rosji, Ukrainy i Białorusi, oraz deklaracji z 26 XII $1991 \mathrm{r}$. o rozwiązaniu ZSRR, przyjętej przez Radę Najwyższą ZSRR.

${ }^{10}$ J. Krukowski, Kościót i państwo. Podstawy relacji prawnych, Lublin 2000, s. 71. Zob. szerzej: M. Kula, Religiopodobny komunizm, Kraków 2003; K. Tyszka, Religijne oblicze komunizmu, „Studia nad Faszyzmem i Zbrodniami Hitlerowskimi” 2009, t. 31.

${ }^{11}$ Por. W. Brzozowski, Państwo wyznaniowe a państwo ideologiczne, w: Państwo wyznaniowe. Doktryna, prawo i praktyka, pod red. J. Szymanka, Warszawa 2011, s. 50-59. 
Należy jednak podkreślić, że wśród państw zamieszkałych w większości czy w istotnej części przez osoby identyfikujące się z islamem konstytucjonalizacja konfesyjnego charakteru państwowości bynajmniej nie jest powszechna. Co więcej, wiele państw należących do Organizacji Współpracy Islamskiej (OWI ${ }^{12}$ jurydyzuje w swoich ustawach zasadniczych zasadę świeckości państwa. Nastąpiło to w konstytucjach: Turcji z 1982 r. (art. 2) $)^{13}$, Gujany z 1980 r. (art. 1) ${ }^{14}$, Togo z 1992 r. $\left(\right.$ art. 1) ${ }^{15}$, Gabonu z 1991 r. (art. 2) ${ }^{16}$, Senegalu z 2001 r. (art. 1) ${ }^{17}$, Mali z 1992 r. (art. 25) ${ }^{18}$, Czadu z 1996 r. (art. 1) ${ }^{19}$, Kirgistanu z 2010 r. (art. 1 ust. 1) ${ }^{20}$, Gwinei Bissau z 1984 r. (art. 1) ${ }^{21}$, Kazachstanu z 1995 r. (art. 1 ust. 1) ${ }^{22}$, Tadżykistanu z1994 r. (art.1) ${ }^{23}$, Turkmenistanu z 2008 r.(art.1) ${ }^{24}$, Beninu z1990 r.(art. 2) ${ }^{25}$,

${ }^{12}$ OWI to międzynarodowa organizacja polityczno-religijna. Ma stałego przedstawiciela przy ONZ. Formalnie powstała w 1971 r. jako Organizacja Konferencji Islamskiej (OKI), chociaż de facto istniała już od konferencji w Rabacie w 1969 r. W czerwcu 2011 r. OKI zmieniła nazwę na obecną, tj. Organizacja Współpracy Islamskiej. Ma na celu popieranie solidarności państw muzułmańskich, zacieśnianie ich współpracy gospodarczej, społecznej, kulturalnej i naukowej, wspólne konsultacje w organizacjach międzynarodowych. W 2016 r. do OWI należało 57 państw, w tym OWP. W ramach OWI działa wiele wyspecjalizowanych instytucji, m.in. Muzułmański Fundusz Solidarności i Islamski Bank Rozwoju. Najwyższym organem jest konferencja przywódców państw członkowskich, zwoływana co trzy lata.

${ }^{13}$ https://global.tbmm.gov.tr/docs/constitution_en.pdf (dostęp: 17 IX 2017).

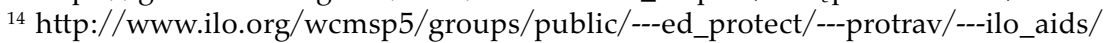
documents/legaldocument/wcms_127724.pdf (dostęp: 14 IX 2017).

${ }^{15}$ https://www.constituteproject.org/constitution/Togo_2007.pdf?lang=en (dostęp: 14 IX 2017).

${ }^{16}$ https://www.constituteproject.org/constitution/Gabon_1997.pdf (dostęp: 14 IX 2017).

${ }^{17}$ https://www.constituteproject.org/constitution/Senegal_2009.pdf?lang=en (dostęp: 17 IX 2017).

${ }^{18}$ https://www.constituteproject.org/constitution/Mali_1992.pdf?lang=en (dostęp: 17 IX 2017).

${ }^{19}$ https://www.presidence.td/fr-page-86-La_Constitution.html (dostęp: 17 IX 2017).

${ }^{20} \mathrm{http}$ ://extwprlegs1.fao.org/docs/pdf/kyr127812E.pdf (dostęp: 17 IX 2017).

${ }^{21}$ https://www.constituteproject.org/constitution/Guinea_Bissau_1991.pdf?lang=en (dostęp: 17 IX 2017).

${ }^{22}$ http://www.constitutionnet.org/sites/default/files/2303_constitution_ kazakhstan1.pdf (dostęp: 17 IX 2017).

${ }^{23} \mathrm{http}$ ://users.unimi.it/dirpubesteuropa/wp-content/uploads/Costituzione-dellaRepubblica-del-Tajikistan.pdf (dostęp: 17 IX 2017).

${ }^{24} \mathrm{https}$ ://www.constituteproject.org/constitution/Turkmenistan_2008.pdf?lang=en (dostęp: 17 IX 2017).

${ }^{25}$ https://www.constituteproject.org/constitution/Benin_1990.pdf?lang=en (dostęp: 17 IX 2017). 
Wybrzeża Kości Słoniowej z 2000 r. (art. 30)26, Kamerunu z 1972 r. $\left(\right.$ art. 1) ${ }^{27}$ czy Burkina Faso z 1991 r. (art. 31) ${ }^{28}$. W konstytucjach Azerbejdżanu ${ }^{29}$ i Nigru $^{30}$ wyrażona jest zasada rozdziału państwa i religii. Natomiast ustrojodawca Ugandy głosi nieistnienie religii państwowej ${ }^{31}$. W konsekwencji w konstytucjach wszystkich wymienionych państw gwarantuje się wolność w sprawach religijnych.

Trzeba odnotować, że tzw. Arabska Wiosna ${ }^{32}$ nie zaowocowała przemianami skutkującymi pozbawieniem islamu statusu religii oficjalnej (państwowej) w określonych państwach. W niektórych krajach muzułmańskich, takich jak Irak ${ }^{33}$, Afganistan czy Somalia ${ }^{34}$, wyraźnie wzrósł stopień nasycenia pierwiastkami konfesyjnymi ustaw zasadniczych przyjętych już w XXI stuleciu w porównaniu z konstytucjami ustanowionymi $\mathrm{w}$ drugiej połowie $\mathrm{XX} \mathrm{w}$. w okresach rządów autorytarnych reżimów, tzn. przed kryzysem, wręcz upadkiem, tych państw na przełomie wieków. Wydaje się, że wspomniane zjawisko odzwierciedla nawrót społeczeństw wymienionych krajów do religii muzułmańskiej po okresie pewnej laicyzacji lansowanej przez władze państwowe mające ambicje modernizacyjne. Można to także interpretować jako efekt oddziaływania ugrupowań fundamentalistów muzułmańskich.

Materiał mający stanowić podstawę rekonstrukcji współczesnych normatywnych znamion państwa konfesyjnego jest relatywnie ograniczony. Przepisy wyznaniowe konstytucji charakteryzują się niejednokrotnie dużą syntetycznością. Regułą nie jest normowanie przez

${ }^{26} \mathrm{https}: / /$ www.constituteproject.org/constitution/Cote_DIvoire_2000.pdf?lang=en (dostęp: 17 IX 2017).

${ }^{27}$ http://www.wipo.int/wipolex/en/text.jsp?file_id=191418 (dostęp: 14 IX 2017).

${ }^{28} \mathrm{https}$ ///www.constituteproject.org/constitution/Burkina_Faso_2012.pdf (dostęp: 17 IX 2017).

${ }^{29}$ Artykuł 18 Konstytucji Azerbejdżanu z 1995 r. - http://azerbaijan.az/portal/Ge neral/Constitution/doc/constitution_e.pdf (dostęp: 14 IX 2017).

${ }^{30}$ Artykuł 30 Konstytucji Nigru z 2010 r. - https://www.constituteproject.org/con stitution/Niger_2010.pdf (dostęp: 14 IX 2017).

${ }^{31}$ Artykuł 7 Konstytucji Ugandy z 1995 r. - https://www.constituteproject.org/con stitution/Uganda_2005.pdf?lang=en (dostęp: 15 IX 2017).

32 Protesty społeczne i konflikty zbrojne w latach 2010-2013 głównie w krajach arabskich Bliskiego Wschodu i Afryki Północnej. Przyczyną ich wybuchu było niezadowolenie obywateli z warunków życiowych, bezrobocie, rosnące ceny żywności, a także nepotyzm i korupcja władz oraz ograniczanie swobód obywatelskich przez autokratyczne reżimy.

${ }_{33}$ Por. Nabiha Hussain Saleh, Doktryna islamu i konstytucje państw arabskich, Warszawa 1993, s. 242-246.

${ }^{34}$ Por. Konstytucje państw afrykańskich, t. 1, oprac. i wstęp L. Gelberg, Warszawa 1963, s. $169-217$. 
ustrojodawcę szczegółowych aspektów relacji państwo-religia. Niekiedy daje się zauważyć wyraźne podobieństwo klauzul wyznaniowych ustaw zasadniczych. Dotyczy to niektórych arabskich państw muzułmańskich oraz państw chrześcijańskich w Europie.

\section{Przejawy wyznaniowego charakteru państwa w obecnych konstytucjach}

U podstaw ustroju państwa wyznaniowego leży odrzucenie przez państwo neutralności (bezstronności) w sprawach religijnych ${ }^{35}$ i przyjęcie określonej doktryny religijnej jako państwowej, oficjalnej czy dominującej. Nie jest jednak regułą otwarta deklaracja ustrojodawcy, że państwo jest państwem religijnym o danej proweniencji. Przykładem może być Deklaracja niepodległości Państwa Izrael z 1948 r., określająca je jako Państwo Żydowskie ${ }^{36}$. Oficjalna nazwa Iranu zgodnie z konstytucją z 1979 r. ${ }^{37}$ to: Islamska Republika Iranu. Podobnie konstytucja Mauretanii z 1991 r. już w art. 1 charakteryzuje ją jako republikę islamska, niepodzielna, demokratyczną i socjalną ${ }^{38}$. Wyznaniowy charakter państwa akcentuje ustrojodawca Afganistanu, w szczególności określając je w pierwszych przepisach Konstytucji z 2004 r. jako Islamską Republikę (zob. art. 1 i 2) $)^{39}$. Podobnie "konstytucja” Arabii Saudyjskiej z 1992 r. cha-

${ }^{35}$ Należy odnotować, że zasada neutralności państwa (władzy państwowej) wobec religii czy światopoglądów jest wprost konstytucjonalizowana wyjątkowo rzadko we współczesnych państwach, które możemy zakwalifikować jako państwa świeckie. Konstytucja Kamerunu w swej preambule głosi, że neutralność i niezależność państwa wobec wszystkich religii są gwarantowane. Jednoznacznie normatywny charakter zasadzie neutralności państwa wobec religii nadają konstytucje: Albanii z 1998 r. (art. 10 ust. 2), Kosowa z 2008 r. (art. 8) i Madagaskaru z 2010 r. (art. 2). Polska konstytucja z 1997 r. $\mathrm{w}$ art. 25 ust. 2 posługuje się synonimem terminu „neutralność”. Stanowi, że władze publiczne zachowują bezstronność w sprawach przekonań religijnych, światopoglądowych i filozoficznych, gwarantując swobodę ich wyrażania w życiu publicznym. Zasada neutralności światopoglądowej państwa jako najistotniejsza cecha współczesnego państwa świeckiego to przede wszystkim rezultat dorobku orzecznictwa sądów konstytucyjnych i administracyjnych. Zob.: M. Pietrzak, op. cit., s. 95; W. Brzozowski, Bezstronność światopoglądowa władz publicznych w Konstytucji RP, Warszawa 2011.

${ }^{36} \mathrm{http}: / /$ libr.sejm.gov.pl/tek01/txt/konst/izrael.html (dostęp: 15 IX 2017).

${ }^{37}$ https://faculty.unlv.edu/pwerth/Const-Iran\%28abridge\%29.pdf(dostęp: 15 IX 2017).

${ }^{38}$ https://www.constituteproject.org/constitution/Mauritania_2012.pdf (dostęp: 15 IX 2017).

${ }^{39} \mathrm{http}: / /$ www.afghanembassy.com.pl/afg/images/pliki/TheConstitution.pdf (dostęp: 3 XI 2017). 
rakteryzuje to królestwo jako suwerenne arabskie, islamskie państwo $\mathrm{z}$ islamem jako jego religią ${ }^{40}$.

Na wyznaniowy charakter państwa wskazuje internalizacja w treści ustawy zasadniczej światopoglądu religijnego. Wyrazem tego zjawiska jest zwłaszcza inwokacja do Boga w preambule konstytucyjnej. Konstytucje: Irlandii z $1937 \mathrm{r}^{41}$ oraz Grecji z $1975 \mathrm{r} .{ }^{42}$ rozpoczynają się od odwołania do trynitarnej koncepcji Absolutu ${ }^{43}$. Konstytucje licznych państw muzułmańskich zawierają, głównie w preambułach, odwołania do Allaha (Boga) oraz jego przymiotów (imion). W Arabii Saudyjskiej widoma, przewidziana przez ustrojodawcę, oznaką konfesyjnego charakteru tego państwa jest jego zielony sztandar $z$ umieszczonym na nim muzułmańskim wyznaniem wiary. W obszernej preambule konstytucji egipskiej z 2014 r. ma miejsce odwołanie do związanych z tym krajem prawd wiary trzech religii monoteistycznych ${ }^{44}$. Inaczej - oględniej na wyznaniowy charakter państwa wskazuje konstytucja marokańska z 2011 r., formułując motto Królestwa: „Bóg, Ojczyzna, Król” ${ }^{45}$. Podobnie motto Kambodży brzmi: „Naród, Religia, Król”. W ten sposób zapewne ustrojodawca wskazuje na najważniejsze wartości, które państwo winno chronić. Niekiedy odwołanie się twórców konstytucji do założeń światopoglądu religijnego jest o wiele bardziej ewidentne - świadczy o interpretacji rzeczywistości politycznej przez pryzmat doktryny religijnej. Podkreśla to konstytucja Iranu z 1979 r., upatrując w Bogu zwierzchnika państwa, czy konstytucja Irlandii z 1937 r., uznając Najświętszą Trójcę za źródło wszelkiej władzy ${ }^{46}$. Stwierdza, że do niej musi odnosić się wszelka działalność człowieka oraz państwa. W wymiarze transcendentalnym poszukuje podstawy stanowionych norm także ustrojodawca indonezyjski, stwierdzając w konstytucji z 1945 r., że „Państwo opiera się na wierze w jednego i Najwyższego Boga" ${ }^{\prime \prime}$.

\footnotetext{
${ }^{40} \mathrm{http}: / /$ www.servat.unibe.ch/icl/sa00000_.html (dostęp: 3 XI 2017).

${ }^{41}$ http://libr.sejm.gov.pl/tek01/txt/konst/irlandia.html (dostęp: 15 IX 2017).

${ }^{42} \mathrm{http}: / /$ libr.sejm.gov.pl/tek01/txt/konst/grecja.html (dostęp: 15 IX 2017).

${ }^{43}$ Wymienione ustawy zasadnicze są jedynymi w Europie ustanowionymi w imię Trójcy Świętej.

${ }^{44}$ https://www.constituteproject.org/constitution/Egypt_2014.pdf (dostęp: 5 XI 2017).

${ }^{45}$ https://www.constituteproject.org/constitution/Morocco_2011.pdf?lang=en (dostęp: 4 XI 2017).

${ }^{46}$ Zob. J. Casey, Państwo i Kościót w Irlandii, w: Państwo i Kościół w krajach Unii Europejskiej, pod red. G. Robbersa, Wrocław 2007, s. 199-200.

${ }^{47} \mathrm{http}$ ://www.ilo.org/wcmsp5/groups/public/---ed_protect/---protrav/---ilo_aids/ documents/legaldocument/wcms_174556.pdf (dostęp: 5 XI 2017).
} 
Relatywnie często spotykaną cechą państwa wyznaniowego jest zadeklarowanie w konstytucji, że określona religia jest religią państwową. Konstytucja Księstwa Monako z 1962 r. ${ }^{48}$ stanowi: „Religia katolicka, apostolska i rzymska jest religią państwa" (art. 9). Podobnie konstytucja Malty z 1964 r. ${ }^{49} \mathrm{~W}$ art. 2 ust. 1 przesądza, iż "religią Malty jest religia Rzymskokatolickiego Kościoła Apostolskiego" ${ }^{\prime 50}$. W ustawach zasadniczych wielu państw muzułmańskich stwierdza się, że ich religią jest islam. Konstytucja mauretańska idzie dalej, głosząc, że „Islam jest religią ludu [podkr. P.B.] i państwa" ${ }^{\prime 1}$. W konstytucji afgańskiej ma natomiast miejsce afirmacja islamu jako religii państwa - zarówno w preambule, jak i wielokrotnie w części normatywnej (np. art. 2, 3 i 35) jest on określany jako religia święta ${ }^{52}$. Ustrojodawca grecki odwołuje się, jak się wydaje, do kryterium socjologicznego, stanowiąc, że "dominującą religią w Grecji jest religia Wschodnioprawosławnego Kościoła Chrystusowego" ${ }^{\prime 53}$. Z kolei twórcy konstytucji Bułgarii z $1991 \mathrm{r} .^{54}$ odwołali się zapewne przede wszystkim do realiów historycznych i kulturowych, gdyż art. 13 ust. 3 wspomnianego aktu stwierdza, że "tradycyjną religią w Republice Bułgarii jest wyznanie prawosławne".

Rangę doktryny religijnej w życiu państwa oraz oficjalny status związków wyznaniowych potwierdza ich konstytucjonalizacja jako taka, a także wysokie miejsce przepisów wyznaniowych w systematyce konstytucji państw konfesyjnych. Ustrojodawca nie łączy bowiem przepisów w przypadkową całość, ale poprzez logiczne uszeregowanie norm wyraża swoją koncepcję państwa, ukształtowaną pod wpływem pewnych koncepcji światopoglądowych oraz założeń politycznych, które popiera i uznaje. Systematyka konstytucji stanowi zatem jedną z ważniejszych przesłanek interpretacyjnych w ramach wykładni

${ }^{48}$ http://libr.sejm.gov.pl/tek01/txt/konst/monako2013.pdf (dostęp: 15 IX 2017).

${ }^{49}$ http://libr.sejm.gov.pl/tek01/txt/konst/malta.html (dostęp: 15 IX 2017).

${ }^{50}$ Zob. U. Mifsud Bonnici, Państwo i Kościół na Malcie, w: Państwo i Kościót..., s. 269-270.

${ }^{51}$ Powyższe stwierdzenie może być wykorzystane dla legitymizacji dyskryminacji w dziedzinie praw obywatelskich oraz w życiu społecznym osób należących do mniejszości religijnych jako sytuujących się poza wspólnotą narodową.

${ }^{52} \mathrm{http}$ ://www.afghanembassy.com.pl/afg/images/pliki/TheConstitution.pdf (dostęp: 5 XI 2017).

${ }^{53}$ Zob. C. Papastathis, Państwo i Kościół w Grecji, w: Państwo i Kościót..., s. 149.

${ }^{54} \mathrm{http}$ ://libr.sejm.gov.pl/tek01/txt/konst/bulgaria2011.html (dostęp: 15 IX 2017). Ustrojodawca bułgarski jest niekonsekwentny, przeczy sobie, ponieważ zarazem w art. 13 ust. 2 głosi, że instytucje religijne są oddzielone od państwa. W rzeczywistości Bułgaria ma znamiona wyznaniowego państwa prawosławnego. 
systemowej i ma duże znaczenie w procesie stosowania ustawy zasadniczej $^{55}$. W państwie wyznaniowym klauzule wyznaniowe zamieszczane są najczęściej wśród zasad podstawowych (naczelnych) ${ }^{56}$, w pierwszych jednostkach systematyzacyjnych (rozdziałach, działach, tytułach, częściach itp.), częstokroć wręcz w pierwszych jednostkach redakcyjnych (artykułach, paragrafach, sekcjach) ${ }^{57}$, określających charakter państwowości, w tym pozycję jednostki. Wpływają one również na ustalenie wszystkich, bardziej szczegółowych przepisów konstytucji, a czasem normy w nich zawarte mogą być stosowane dla ustalenia zachowań pewnych podmiotów jako podstawa wyłączna ${ }^{58}$. W niektórych współczesnych ustawach zasadniczych państw wyznaniowych status wyznania oficjalnego jest określony $w$ jednostce systematyzacyjnej poświęconej prawom i wolnościom człowieka i obywatela, czemu nierzadko towarzyszą próby pogodzenia aprecjacji jednej konfesji z wolnością sumienia i wyznania lub zasadą równości związków wyznaniowych ${ }^{59}$. Wyjątkowo ustrojodawca sprawom wyznaniowym poświęca, jak w konstytucji Islandii z 1944 r. (Rozdział VI), Danii z 1953 r. (Część VII) czy Sri Lanki z 1978 r. (Rozdział II), specjalną jednostkę systematyzacyjną.

W państwach wyznaniowych dochodzi do osłabienia, a niekiedy wręcz do wykluczenia autonomii prawa stanowionego wobec norm o charakterze religijnym. W Arabii Saudyjskiej za konstytucję uznaje się Koran i Sunnę Proroka ${ }^{60}$. Podobne stanowisko prezentuje ustrojodawca somalijski, stanowiąc, że konstytucja tego państwa "opiera się na fundamentach Świętego Koranu i Sunny naszego proroka Mohameda". $\mathrm{W}$ wielu arabskich państwach muzułmańskich szariat traktowany jest przez ustrojodawców jako podstawa, lub też źródło prawodawstwa, a niekiedy dodatkowo formułowany jest wymóg niesprzeczności z nim prawa stanowionego. Konstytucja Iraku z 2005 r. stanowi ogólnie, że

${ }^{55}$ Zob. B. Banaszak, Prawo konstytucyjne, Warszawa 1999, s. 71.

${ }^{56}$ Por. R.R. Ludwikowski, Prawo konstytucyjne porównawcze, Toruń, 2000, s. 182.

${ }^{57}$ Por. np. art. 3 konstytucji Grecji z 1975 r., § 2 i 4 Konstytucji Norwegii, § 4 Konstytucji Danii z 1953 r., sekcja 2 konstytucji Malty z 1964 r., art. 9 konstytucji Monako z 1962 r., art. 2 konstytucji Algierii z 1996 r., art. 2 konstytucji Egiptu z 2014 r., art. 1 konstytucji Tunezji z 2014 r.

${ }^{58}$ P. Sarnecki, Systematyka konstytucji, w: Charakter i struktura norm konstytucji, pod red. J. Trzcińskiego, Warszawa 1997, s. 24-25.

${ }_{59}$ Por. np. art. 43 konstytucji Kambodży z 1993 r., art. 11 konstytucji Andory z 1993 r., art. 37 konstytucji Lichtensteinu z 1921 r.

${ }^{60}$ Zdaniem m.in. Nabihy Hussain Saleh (op. cit., s. 97) Koran stanowi konstytucję wszystkich islamskich konstytucji. 
islam jest podstawowym źródłem prawodawstwa. Nie może zostać ustanowione żadne prawo sprzeczne z jego przepisami. Według współczesnego art. 4 konstytucji irańskiej „Wszystkie prawa cywilne, karne, finansowe, ekonomiczne, administracyjne, kulturalne, militarne, polityczne oraz inne przepisy prawne powinny być wzorowane na nakazach islamu" ${ }^{\prime 61}$. W licznych państwach islamskich normy religijne mają zatem formalnie, zwłaszcza konstytucyjnie, zagwarantowaną wyższość nad prawem stanowionym. Sa traktowane jako jego zasadniczy determinant. Konstytucja Somalii otwarcie wskazuje, że szariat ma wyższość nawet nad samą ustawą zasadniczą ${ }^{62}$.

W państwie wyznaniowym szeroko rozumiana doktryna religijna przynajmniej inspiruje prawo stanowione, w tym m.in. treści konstytucyjne. W ustawach zasadniczych wielu państw katolickich dostrzegalny jest wpływ katolickiego nauczania moralnego i społecznego, które choć nie dostarcza wzorców instytucji polityczno-ustrojowych, to determinuje aksjologię konstytucyjna, odzwierciedloną w katalogu praw i wolności obywatelskich, ewentualnie w konstytucyjnych zasadach polityki społeczno-gospodarczej państwa. Ustrojodawca irlandzki uznaje prawo do życia nienarodzonych $\mathrm{w}$ związku $\mathrm{z}$ równie chronionym prawem matki do życia oraz gwarantuje jego respektowanie przez prawo. Podobnie konstytucja Andory „uznaje prawo do życia i chroni je całkowicie w różnych jego fazach". Przedmiotem szczególnej troski jest rodzina traktowana jako podstawa społeczeństwa, czy wręcz - jak w Irlandii jako „instytucja moralna”. W związku z tym państwo zapewnia jej pomoc i opiekę, tworząc szczegółowe gwarancje konstytucyjne. Ustrojodawca Andory uznaje prawo każdej osoby do pracy, do jej rozwoju przez prace oraz do dochodu gwarantującego człowiekowi i jego rodzinie życie odpowiadające ludzkiej godności. Państwo irlandzkie natomiast ma konstytucyjny obowiązek zapewnienia matkom, aby warunki ekonomiczne nie zmuszały ich do pracy kolidującej z obowiązkami domowymi. Za podstawę rodziny zostaje we wspomnianych krajach katolickich uznane małżeństwo, które państwo otacza szczególną troską, utrudniając jego rozwiązanie, czy wręcz wykluczając rozwody ${ }^{63}$.

${ }^{61}$ M. Stolarczyk, Iran. Państwo i religia, Warszawa 2001, s. 270.

${ }^{62}$ Zob. art. 4 ust. 1 konstytucji Somalii z 2012 r.

${ }^{63}$ Na przykład w Księstwie Lichtensteinu ustawa o małżeństwie z 13 XII 1973 r., pozostając pod wpływem doktryny katolickiej, definiuje małżeństwo jako całkowitą i niepodzielną wspólnotę życiową dwojga ludzi odmiennej płci i wyraźnie stoi na gruncie zasady nierozwiązywalności małżeństwa, określając rozwód jako wyjątek. 
Troska o rodzinę wynikająca z motywacji religijnych jest dostrzegalna także w konstytucjach państw islamskich. Rodzina jest postrzegana jako miejsce kształtowania postaw tradycjonalistycznych. Została ona uznana - podkreślili to m.in. ustrojodawcy Bahrajnu (2002), Egiptu (2014), Kuwejtu (1962) oraz Jemenu (1991) - za podstawę społeczeństwa, a opiera się na religii, moralności i patriotyzmie. „Rodzina jest głównym źródłem rozwoju i ewolucji ludzkości" ${ }^{\prime \prime 4}$. W związku z tym państwo roztacza nad nią opiekę. Teokratyczna doktryna islamu dostarcza nie tylko wzorców życia społecznego, lecz także polityczno-ustrojowych. Na szczególną uwagę zasługuje koncepcja konsultacji tzw. szury, do której odwołują się wszelkie znaczące siły polityczne krajów islamskich. Beduińska tradycja konsultacji została sakralizowana przez Koran, którego sura III, 159 stwierdza: „zasięgaj ich rady w każdej sprawie", zaś sura XLII, 38 mówi, że nagroda jest przewidziana także: "dla tych, których sprawy są przedmiotem wzajemnej narady". Współczesne konstytucje w państwach bliskowschodnich nawiązują do nakazu konsultacji. Przewidują zamiast parlamentów albo równolegle z nimi, jak egipska, omańska (1996) czy saudyjska, rady konsultacyjne (szura). Ustawy zasadnicze mogą także ustanawiać organy doradcze, skupiające notabli w formie zgromadzenia (madżlis). Są one często zwane madżlis asz-szura ${ }^{65}$. Z kolei wpływ idei pacyfistycznych o konotacji buddyjskiej dostrzegalny jest w konstytucjach krajów, w których buddyzm jest religią dominującą. W szczególności ustrojodawca kambodżański w 1993 r. postawił sobie za cel odnowienie Kambodży jako Wyspy Pokoju o wielopartyjnym, liberalno-demokratycznym ustroju.

Relatywnie często występującym w konstytucjach państw wyznaniowych przejawem ich konfesyjnego charakteru jest wymóg przynależności do religii oficjalnej piastuna stanowiska głowy państwa. Jest on bowiem uosobieniem państwowości, jej żywym symbolem. Ustawy zasadnicze mogą wprost formułować wymóg wyznawania określonej religii lub przynależności do danego Kościoła. Ewentualnie konfesyjny światopogląd oficjeli gwarantowany jest przez religijną, obligatoryjną przysięgę, której złożenie jest wymogiem objęcia urzędu. Konstytucja norweska nadal wymaga od króla wyznawania religii ewangelicko-augsburskiej (§ 4), choć Kościół luterański stracił od 2017 r. charakter wyznania oficjalnego. Podobnie w Szwecji, pomimo ustanowionego

${ }^{64}$ Preambuła Konstytucji Republiki Iranu z 1979 r., zob. M. Stolarczyk, op. cit., s. 62.

${ }^{65}$ Zob. A. Mrozek-Dumanowska, Islam a demokracja, w: Islam a demokracja, pod red. A. Mrozek-Dumanowskiej, Warszawa 1999, s. 19-20. 
od 2000 r. rozdziału państwa i Kościoła, wciąż istnieje wymóg, aby król był "czystego wyznania ewangelicko-augsburskiego, w formie przyjętej i ogłoszonej na spotkaniu w Uppsali w roku 1593; także książęta i księżniczki Domu Królewskiego powinny być wychowywane w tym samym wyznaniu"66. W wymienionych krajach skandynawskich wymaga się od monarchy nie tylko wyznawania światopoglądu religijnego danego rodzaju, ale także jego propagowania. Konstytucja duńska ogranicza się do wymogu członkostwa króla w Kościele Ewangelicko-Augsburskim (§ 6). Brytyjska ustawa z 1700 r. o następstwie tronu formułuje cenzus wyznaniowy od strony niejako negatywnej, wykluczając objęcie tronu przez katolików. Przewiduje także obligatoryjne członkostwo monarchy w Kościele anglikańskim ${ }^{67}$. Konstytucja Tajlandii stanowi, że król jest buddystą i poplecznikiem religii. $W$ państwach muzułmańskich szczególnie częsty jest konstytucyjny wymóg wyznawania islamu przez głowę państwa ${ }^{68}$. Konstytucja Omanu z 1996 r. formułuje dla sukcesora tronu nawet bardziej wygórowane wymogi - winien być on przede wszystkim dorosłym muzułmaninem, prawowitym synem rodziców muzułmanów (zob. art. 5) ${ }^{69}$. Natomiast konstytucja Malediwów z 2008 r. zakłada, że prezydentem będzie muzułmanin-sunnita. We wspomnianych państwach jednym $z$ instrumentów zapewnienia islamskiego wyznania głowy państwa jest konstytucyjny wymóg przysięgi religijnej w imię Allaha, jak np. w Somalii, czy w imię Miłosiernego Boga, jak np. w Egipcie, względnie - Allahowi Wszechmogącemu, jak w Autonomii Palestyńskiej. Z kolei konstytucja grecka wymaga od prezydenta tego państwa złożenia przysięgi „w imię Trójcy Świętej, Jedynej i Niepodzielnej" (zob. art. 33 ust. 2). Przesądza to przynajmniej o chrześcijańskim światopoglądzie elekta.

Wyjątkowo spotykamy w konstytucjach, nawet państw islamskich, wymogi wyznawania religii oficjalnej przez piastunów innych organów władzy niż tylko urząd głowy państwa. Przykładem może być konstytucja Afganistanu z 2004 r., obligująca ministrów do złożenia przysięgi religijnej zawierającej zobowiązanie protekcji wobec islamu. Konstytucja Iraku z 2005 r. przewiduje obligatoryjną religijną przysięgę

${ }^{66}$ Zob. § 4 Aktu o Sukcesji z dnia 26 IX 1810 r. w brzmieniu tekstu jednolitego z 29 XI 1979 r. - http://libr.sejm.gov.pl/tek01/txt/konst/szwecja.html (dostęp: 2 XI 2017).

${ }^{67} \mathrm{http}: / /$ libr.sejm.gov.pl/tek01/txt/konst/brytania.html (dostęp: 3 XI 2017).

${ }^{68}$ Zob. np. art. 73 ust. 1 konstytucji Algierii z 1976 r. - http://www.servat.unibe.ch/ icl/ag00000_html (dostęp: 2 XI 2017).

${ }^{69} \mathrm{http}: / /$ www.servat.unibe.ch/icl/mu00000_html (dostęp: 2 XI 2017). 
członków Izby Reprezentantów ${ }^{70}$. Cenzus wyznaniowy przy obsadzie organów przedstawicielskich jest w konstytucjach państw konfesyjnych przewidziany wyjątkowo rzadko. Konstytucja Iranu z 1979 r. przewiduje, że do Zgromadzenia Konsultacyjnego (Madżlisu) po jednym przedstawicielu wybierają Zaratustrianie i Żydzi. Chrześcijanie chaldejscy i aramejscy mają być reprezentowani wspólnie przez jednego przedstawiciela, zaś chrześcijanie armeńscy z północy i z południa mają wybierać po jednym przedstawicielu (art. 64) ${ }^{71}$. Podobnie konstytucja Pakistanu z 1973 r. zakłada limitowanie w Zgromadzeniu Narodowym i w parlamentach prowincjonalnych mandatów piastowanych przez muzułmanów i niemuzułmanów. Oryginalne rozwiązanie, oparte na powiązaniu kryteriów wyznaniowych i politycznych, przewiduje konstytucja Libanu z 1926 r. W tamtejszym Senacie winni zasiadać przedstawiciele wszystkich wspólnot wyznaniowych, natomiast wybory do Izby Deputowanych winny opierać się na równej reprezentacji między chrześcijanami i muzułmanami.

Wyznaniowy charakter państwa skutkuje podważeniem odrębności organizacyjnej lub funkcjonalnej aparatu państwowego i wyznania oficjalnego, na co wskazują niektóre ustawy zasadnicze. Skrajnym przypadkiem jest przejęcie przez organy wyznaniowe funkcji organów państwowych. Ewidentnymi przykładami takiego ustroju są Islamska Republika Iranu ${ }^{72}$ oraz Państwo Watykańskie. W Iranie funkcje zwierzchnika państwa odpowiedzialnego tylko przed Bogiem pełni Duchowy Przywódca Narodu (Faghih), zarazem zwierzchnik religijny tamtejszych szyitów. Konstytucja z 1979 r. przyznaje mu większe kompetencje niż konstytucja z 1906/1907 r. przyznawała szachowi ${ }^{73}$. W szczególności określa on główne założenia ustrojowe państwa i nadzoruje ich realizację. Jest zwierzchnikiem sił zbrojnych, obsadza najwyższe stanowiska

${ }^{70} \mathrm{https}$ ://www.constituteproject.org/constitution/Iraq_2005.pdf?lang=en (dostęp: 3 XI 2017).

${ }^{71} \mathrm{http}: / /$ www.wipo.int/edocs/lexdocs/laws/en/ir/ir001en.pdf (dostęp: 3 XI 2017).

${ }^{72}$ Islam nie wykształcił struktur organizacyjnych podobnych do chrześcijańskich. W szczególności wspólnota polityczna od początku utożsamiana była ze wspólnotą wyznaniową. Doprowadziło to do przejmowania przez państwo funkcji organizacyjnych w sprawach religijnych. Jak bowiem głosi konstytucja Republiki Islamskiej Iranu, „Państwo z punktu widzenia islamu nie jest produktem żadnej z klas społecznych czy też supremacją jednostek. Jawi się raczej jako krystalizacja politycznych ideałów ludzi tej samej religii i światopoglądu, którzy przyznają sobie prawo, by w procesie rozwoju światopoglądu i przekonań religijnych skierować się na drogę wiodącą ku celowi ostatecznemu, którym jest Bóg" (M. Stolarczyk, op. cit., s. 259).

${ }^{73}$ Ibidem, s. 121. 
państwowe, w tym posady członków Rady Nadzorującej, zwierzchników: wymiaru sprawiedliwości, radia i telewizji, Sztabu Mieszanego, Korpusu Strażników Rewolucji Islamskiej, sił zbrojnych i porządkowych. Faghih zatwierdza lub odwołuje prezydenta Iranu, biorąc pod uwagę preferencje społeczeństwa i decyzje Najwyższej Rady Sądownictwa oraz Rady Nadzorującej. Występuje jako arbiter i koordynator trzech rodzajów władz: wykonawczej, ustawodawczej i sądowniczej. Podlega mu Rada Nadzorująca, organ złożony z sześciu islamskich teologów i sześciu wybitnych prawników muzułmańskich. Zadaniem wspomnianego organu jest interpretacja konstytucji oraz cenzurowanie ustawodawstwa parlamentu pod względem jego zgodności z islamem i konstytucją, co stanowi warunek jego wejścia w życie. W Pakistanie według konstytucji z 1973 r. Federalny Sąd Szariatu może z urzędu bądź na wniosek badać kwestię sprzeczności danej ustawy lub innych przepisów z nakazami islamu, określonymi przez Koran i Sunnę. W Jordanii na mocy konstytucji z 1952 r. sądy religijne, tzn. muzułmańskie sądy szariackie oraz sądy innych wspólnot religijnych, stanowią integralny element systemu sądownictwa państwowego.

Z kolei konstytucja Watykanu z 2000 r. stanowi jednoznacznie: „Najwyższy Kapłan [papież - dop. P.B.] - Suweren Państwa Miasto Watykan ma pełnię władzy ustawodawczej, wykonawczej i sądowniczej"74. Wśród państw o charakterze chrześcijańskim podważenie odrębności instytucjonalnej aparatu państwowego i kościelnego jest rzadkością: w Andorze funkcję jednego z dwóch co-princepsów sprawuje biskup Urgell $^{75}$, na mocy Act of Supremacy z 1534 r. król nadal jest uważany za "głowę Kościoła w Anglii"76. W sumie w Europie monizm organizacyjny aparatu wyznaniowego i państwowego uległ przezwyciężeniu od okresu sporu o inwestyturę w XI-XII w.

Konstytucje państw wyznaniowych wskazują niekiedy na zanik rozdziału funkcjonalnego między państwem a oficjalną religią. Państwo przejmuje zwłaszcza obowiązek jej propagowania. Zgodnie z art. 14 Konstytucji Lichtensteinu troska o ochronę w szczególności interesów religijnych i moralnych narodu to jedno z naczelnych zadań państwa.

${ }^{74}$ http://libr.sejm.gov.pl/tek01/txt/konst/watykan-01.html (dostęp: 3 XI 2017).

${ }^{75}$ Drugim co-princepsem jest prezydent Francji jako sukcesor dawnych królów tego kraju. Pozycję ustrojową co-princepsów określa Tytuł III (art. 42-49) konstytucji Andory z 1993 r.

${ }^{76}$ Szerzej na temat statusu Kościoła Anglii zob. T.J. Zieliński, Państwowy Kościół Anglii. Studium prawa wyznaniowego, Warszawa 2016. 
Wspomniane zaangażowanie jest wręcz wpisane w istotę wielu państw islamskich. Irańska ustawa zasadnicza stwierdza wprost, że "celem państwa jest kształtowanie ludzi na wzór boski [...], by przygotować podłoże do pojawienia się i rozkwitu talentów ludzkich świadczących o wielkości Boga"77. Zgodnie z "konstytucją" saudyjską z 1992 r. określeni członkowie rządu ponoszą solidarną odpowiedzialność przed królem za wprowadzanie islamskiego szariatu, z kolei irańskie radio i telewizja, kierując się założeniami rewolucji islamskiej, mają konstytucyjny obowiązek służenia propagowaniu kultury muzułmańskiej oraz ochrony przed wpływami antymuzułmańskimi. Również siły zbrojne Republiki Islamskiej, określane przez ustrojodawcę wprost jako "Armia ideologii", mają za zadanie nie tylko obronę i bezpieczeństwo granic, lecz także propagowanie doktryny dżihadu, „walkę na drodze Boga, walkę dla rozprzestrzenienia suwerenności prawa boskiego w świecie" ${ }^{\prime \prime 7}$.

Szczególnym wyrazem zaangażowania państwa w propagowanie doktryny religijnej jest organizowanie przez nie nauki religii w szkolnictwie publicznym (państwowym). Podkreśla to ustrojodawca grecki, który uznając za cel kształcenia m.in. edukację moralną Greków oraz rozwój ich świadomości religijnej, określa je jako podstawową misję państwa. Podobnie według art. 15 konstytucji Lichtensteinu kształcenie religijno-etyczne stanowi część ogólnego procesu wychowania i oświaty. W związku z tym zadaniem szkół publicznych jest wychowywanie młodych ludzi zgodnie z zasadami chrześcijańskimi. Konstytucja maltańska z 1964 r. bezpośrednio nakłada obowiązek zapewnienia przez szkoły państwowe nauczania "Rzymskiej Katolickiej Apostolskiej Wiary”. Odpowiednio, ustawodawca saudyjski za główny cel edukacji uznał wpajanie wiary islamskiej młodemu pokoleniu.

Konsekwencją uznania określonej religii za państwową (oficjalną) jest odrzucenie przez ustrojodawcę zasady równości czy równouprawnienia związków wyznaniowych. Przemilczają ją konstytucje wszystkich państw wyznaniowych ${ }^{79}$. Związek wyznaniowy reprezentujący religię państwową (oficjalną) z punktu widzenia formalno-prawnego uzyskuje uprzywilejowaną pozycję. Jest wspierany przez państwo. Jednoznacznie

${ }^{77}$ M. Stolarczyk, op. cit., s. 260.

${ }^{78}$ Ibidem, s. 262. Podobnie ustrojodawca saudyjski jako pierwszoplanowe zadania armii wskazał obronę religii muzułmańskiej i jej dwóch świętych miejsc - Mekki i Medyny.

${ }^{79}$ Trzeba przyznać, że zasada równości (równouprawnienia) związków wyznaniowych jest stosunkowo rzadko wprost wyrażana w konstytucjach państw dających się zakwalifikować jako państwa świeckie. 
przewiduje to konstytucja Islandii z 1944 r. ${ }^{80}$, stanowiąc, że Kościół Ewangelicko-Luterański będzie w tym kraju Kościołem państwowym i jako taki będzie wspierany i chroniony przez państwo. Bardzo podobne gwarancje wobec Ewangelickiego Kościoła Luterańskiego formułuje duńska ustawa zasadnicza z 1953 r. ${ }^{81}$ Natomiast w Księstwie Lichtensteinu zgodnie $\mathrm{z}$ art. 37 ust. 2 jego konstytucji z $1921 \mathrm{r}^{82}$ Kościołem państwowym jest Kościół rzymskokatolicki i jako taki jest w pełni chroniony przez państwo. Konstytucja Sri Lanki z 1978 r. ogólnie stanowi, że państwo przyznaje pierwszeństwo buddyzmowi. Ustrojowym obowiązkiem państwa jest chronić i wspierać „Buddę Sasana” (art. 9) ${ }^{83}$.

Niekiedy w konstytucjach spotykamy szczegółowe gwarancje dla wybranych instytucji wyznania oficjalnego. Ustrojodawca saudyjski przyjął na siebie zobowiązanie do troski o święte miejsca islamu oraz opieki nad pielgrzymami. Szczególnie liczne gwarancje dla prawosławia zawiera konstytucja Grecji. W szczególności zapewnia uprzywilejowany, autonomiczny status Górze Athos (art. 105). W aspekcie duchowym Góra Athos podlega bezpośredniej jurysdykcji Patriarchatu Ekumenicznego. Zgodnie z grecką ustawą zasadniczą wszyscy ci, którzy żyją tam jako zakonnicy, otrzymują obywatelstwo greckie od momentu nowicjatu, bez konieczności dopełniania dodatkowych formalności. Góra Athos jest zarządzana, zgodnie ze swoim ustrojem, przez dwadzieścia świętych klasztorów, na które podzielony jest Półwysep Athos; jego terytorium jest niezbywalne. Konstytucja przewiduje, że administracja Góry Athos sprawowana jest przez reprezentantów świętych klasztorów, które tworzą Świętą Wspólnotę. Zabronione jest dokonywanie jakichkolwiek zmian w systemie administracyjnym dotyczącym liczby klasztorów na Górze Athos, jak również w ich porządku hierarchicznym i stosunkach z poddanymi. Ustrojodawca zabronił osiedlania się innowierców i schizmatyków na omawianym terytorium. Szczegółowe określenie statusu Góry Athos oraz zasad jej funkcjonowania zawarte jest w Karcie Statutowej Góry Athos, opracowanej i przyjętej przez dwadzieścia świętych

${ }^{80} \mathrm{http}: / /$ www.government.is/constitution/ (dostęp: 15 IX 2017). W referendum konstytucyjnym w 2012 r. obywatele Islandii opowiedzieli się za utrzymaniem dotychczasowego statusu Kościoła Ewangelicko-Luterańskiego.

${ }^{81}$ Zgodnie z \& 4 konstytucji Danii „Ewangelicki Kościół Luterański jest kościołem państwowym Danii i jako taki jest wspierany przez państwo" - http://libr.sejm.gov.pl/ tek01/txt/konst/dania.html (dostęp: 15 IX 2017).

$82 \mathrm{http}: / /$ hrlibrary.umn.edu/research/liechtenstein-constitution.pdf (dostęp: 15 IX 2017).

${ }^{83}$ https://www.parliament.lk/files/pdf/constitution.pdf (dostęp: 3 XI 2017). 
klasztorów z udziałem reprezentantów państwa oraz ratyfikowanej przez Patriarchat Ekumeniczny i grecką Izbę Deputowanych. Ścisłe przestrzeganie ustroju Góry Athos w aspekcie życia duchowego znajduje się pod najwyższym nadzorem Patriarchatu Ekumenicznego, a w aspekcie administracyjnym - pod nadzorem państwa. Na państwie spoczywa wyłączny obowiązek utrzymania porządku i bezpieczeństwa publicznego. Jego uprawnienia wymienione w konstytucji są wykonywane przez gubernatora, którego prawa i obowiązki określa ustawa. Ustawa określa także władzę sądowniczą sprawowaną przez władze klasztorne i Świętą Wspólnotę oraz przywileje celne i podatkowe nadane Górze Athos. Grecka ustawa zasadnicza przewiduje także gwarancje majątkowe dla innych instytucji prawosławnych. Zgodnie z jej art. 18 ust. 3 własność ziemska klasztorów patriarszych Świętej Anastazji Pharmacolytria na Półwyspie Chalcydyckim, Świętego Wlatadesa w Salonikach i Świętego Jana Ewangelisty Teologa w Patmos, z wyjątkiem terenów zależnych, nie może być wywłaszczona. Wywłaszczeniu nie podlegają także dobra patriarchatów: Aleksandrii, Antiochii i Jerozolimy oraz Świętego Klasztoru na Synaju. W istocie rzeczy gwarancją przede wszystkim dla Kościoła prawosławnego w Grecji jest konstytucyjny zakaz prozelityzmu innych związków wyznaniowych (zob. art. 13 ust. 2) ) $^{84}$. Konstytucja grecka gwarantuje także sprawy stricte religijne, a mianowicie niezmienność tekstu Pisma Świętego. Zabronione jest oficjalne tłumaczenie Biblii bez zgody Kościoła Autokefalicznego Grecji i Patriarchatu Ekumenicznego w Konstantynopolu (zob. art. 103 ust. 3). Artykulacja w ustawach zasadniczych państw wyznaniowych tak licznych i szczegółowych gwarancji dla konfesji oficjalnej jak w Grecji należy jednak do rzadkości.

W egipskiej ustawie zasadniczej zapewniono status muzułmańskiemu uniwersytetowi Al-Azhar ${ }^{85}$. Jest to niezależna, naukowa instytucja islamska, posiadającą wyłączne kompetencje nad własnymi sprawami. Konstytucja z 2014 r. gwarantuje, że jest to główna władza nauk religijnych i spraw islamskich. Zarazem Al-Azhar jest odpowiedzialny za głoszenie islamu i rozpowszechnianie nauk religijnych, a także języka

${ }^{84} \mathrm{Z}$ formalnego punktu widzenia ochrona przed prozelityzmem obejmuje w Grecji wszystkie tzw. religie znane.

${ }_{85}$ Teologiczna uczelnia muzułmańska w Kairze. Uniwersytet określany jest mianem najbardziej renomowanej instytucji oświaty islamu sunnickiego. Na gruncie teologicznym władze uniwersytetu uznają cztery sunnickie szkoły prawa muzułmańskiego (wliczając w to bractwa sufickie), mając zarazem stosunek antagonistyczny wobec fundamentalistycznych ruchów reformatorskich takich jak wahhabizm i salafizm. 
arabskiego w Egipcie i na świecie. Państwo zostało zobowiązane do zapewnienia wystarczających przydziałów finansowych, aby osiągnąć cele uniwersytetu. Przewidziano konstytucyjne gwarancje niezależności organizacyjnej Al-Azhar. Jego Wielki Szejk jest niezależny i nie może zostać zwolniony. Sposób mianowania Wielkiego Szejka spośród Rady Starszych Nauczycieli określa prawo.

Ceną, jaką ponosi wyznanie oficjalne w zamian za wsparcie ze strony państwa, może być ograniczenie jego wewnętrznej autonomii i niezależności. W Grecji państwo jest strażnikiem ortodoksyjnego charakteru Kościoła prawosławnego. Konstytucja z 1975 r. przesądza, że jest on nierozerwalnie związany w swoich dogmatach $\mathrm{z}$ Patriarchatem Ekumenicznym oraz „ze wszystkimi innymi kościołami chrześcijańskimi uznającymi te dogmaty, przestrzegając niezmiennie, podobnie jak te kościoły, świętych kanonów apostolskich i synodalnych oraz świętych tradycji"86. Państwo wyznacza zatem zarówno kwestie wewnętrzne, jak i granice ewolucji dogmatycznej w Kościele ${ }^{87}$. Ustawa zasadnicza przesądza także najważniejsze zagadnienia wewnątrzorganizacyjne, stanowiąc, że „Kościół jest autokefaliczny i zarządzany przez Święty Synod, w którego skład wchodzą sprawujący aktualnie swe funkcje biskupi, oraz przez Stały Święty Synod, który, wywodząc się ze Świętego Synodu, jest tworzony, tak jak jest to określone w Karcie Statutowej Kościoła i zgodnie z postanowieniami Księgi Patriarchalnej z 29 czerwca 1850 r. oraz Aktu Synodalnego z 4 września 1928 r.". W Bhutanie zgodnie z art. 3 ust. 4 konstytucji z 2008 r. król mianuje, na podstawie rekomendacji Pięciu Loponsów (Nauczycieli), lidera tamtejszego buddyzmu - Jego Świątobliwość Je Khenpo.

Skutkiem wyznaniowego charakteru państwa jest częstokroć ograniczenie wolności w sprawach religijnych. Należy jednak podkreślić, że rzadko znajduje to wyraz w ustawach zasadniczych. Przykładem może być konstytucja Somalii z 2012 r., która wyjątkowo stanowczo, bowiem już w art. 2 ust. 2, a następnie w art. 17 ust. 2, wprowadza zakaz

${ }^{86}$ Zasada jedności greckiego Kościoła prawosławnego z innymi Kościołami prawosławnymi została po raz pierwszy wprowadzona przez ustawodawcę w $1844 \mathrm{r}$. w związku z arbitralnym ustanowieniem w 1833 r. autokefalii z królem jako głową Kościoła, co doprowadziło do zerwania łączności kanonicznej z innymi Kościołami prawosławnymi. Parlament grecki, wprowadzając analizowaną zasadę, pragnął zapewnić prawosławny charakter Kościoła nowego państwa.

${ }^{87}$ Por. A. Pikulska-Robaszkiewicz, Stosunki między państwem a Kościołami w Grecji, „Prawo Kanoniczne" 1998, nr 3-4, s. 255-258. 
propagowania w tym państwie innej religii niż islam ${ }^{88}$. Częściej ustrojodawca przemilcza gwarancje dla wolności w sprawach religijnych. Takiego zaniechania dopuszczono się w konstytucjach: Arabii Saudyjskiej z 1992 r., Afganistanu z 2004 r. czy Malediwów z 2008 r. ${ }^{89}$ Większość państw wyznaniowych gwarantuje wszakże w swoich konstytucjach wolność religijną. Natomiast niejednokrotnie istnieją konstytucyjne ograniczenia wolności religijnej głowy państwa będące konsekwencją ustrojowego wymogu wyznawania religii oficjalnej.

\section{Podsumowanie}

Reasumując, trzeba stwierdzić, że konstytucje współczesnych państw wyznaniowych podkreślają różne aspekty powiązania wspólnot religijnych z państwem, jednak kompleksowe i względnie szczegółowe unormowanie obecności religii na forum publicznym zawierają głównie ustawy zasadnicze niektórych państw islamskich oraz Grecji. Skonstruowanie szczegółowego, uniwersalnego modelu państwa wyznaniowego na podstawie dorobku współczesnego konstytucjonalizmu jest, jak się wydaje, niemożliwe ${ }^{90}$. Jako najczęściej występujące jego znamiona należy wskazać: odrzucenie neutralności światopoglądowej, przyjęcie danej religii jako oficjalnej, wymóg przynależności głowy państwa do konfesji oficjalnej bądź wyznawania światopoglądu religijnego w ogóle, negacja zasady równości (równouprawnienia) związków wyznaniowych czy ustrojowe gwarancje poparcia dla danego wyznania. $Z$ perspektywy obecnie obowiązujących ustaw zasadniczych w pewnym stopniu adekwatna jest dualistyczna klasyfikacja państw wyznaniowych na te w wersji klasycznej (zamkniętej, "twardej") i w wersji tolerancyjnej (otwartej, „,miękkiej”) ${ }^{91}$. W najnowszym ustrojodawstwie obserwujemy tendencje przeciwstawne. W sumie, generalnie rzecz

\footnotetext{
${ }^{88}$ https://www.constituteproject.org/constitution/Somalia_2012.pdf?lang=en (dostęp: 2 XI 2017).

${ }^{89}$ Wyczerpująco na temat wolności w sprawach religijnych w państwach członkowskich Organizacji Konferencji Islamskiej zob. W. Bar, Wolność religijna w Dār al-Islām, Lublin 2003.

${ }^{90}$ Por. J. Szymanek, Państwo wyznaniowe, w: Leksykon prawa wyznaniowego. 100 podstawowych pojęć, pod red. A. Mezglewskiego, Warszawa 2014, s. 291.

${ }^{91}$ Zob.: J. Szymanek, op. cit., s. 293-294; T.J. Zieliński, Państwo wyznaniowe - analiza typologiczna, w: Państwo wyznaniowe..., s. 19-49; J. Krukowski, Konkordaty współczesne. Doktryna, teksty (1964-1995), Warszawa 1995, s. 44-46.
} 
ujmując, można zauważyć, że nasycenie konstytucji współczesnych państw klauzulami wyznaniowymi maleje. Należy przy tym jednak zaznaczyć, że samookreślenie państwa ze względu na religię czy światopogląd w konstytucji to nie jedyny spotykany w praktyce politycznej sposób na wskazanie jego wyznaniowego charakteru ${ }^{92}$.

Rodzi się pytanie o realną możliwość wykonywania przez jednostkę uprawnień wynikających z wolności sumienia i wyznania przy braku ich podstawowej gwarancji - rozdziału państwa i związków wyznaniowych. Analiza realiów wyznaniowych krajów europejskich, zwłaszcza zaś Wielkiej Brytanii, Norwegii czy Danii, prowadzi do wniosku, że nie można a priori wykluczyć pozytywnej odpowiedzi. Wówczas jednak ciężar obrony praw człowieka w sprawach religijnych zostaje przesunięty z gwarancji formalnych (konstytucyjnych) na mające dynamiczny charakter gwarancje materialne, do których zaliczyć można m.in. związaną ze wzrostem poziomu życia laicyzację społeczeństwa, rozwój idei praw człowieka, pluralizm kulturowy obywateli czy swobodę komunikacji. W sumie wydaje się możliwa do pogodzenia z wolnością religijną jakaś forma interwencjonizmu państwowego, polegająca głównie na aktywnym wspieraniu niektórych ugrupowań religijnych ${ }^{93}$.

\section{CHARACTERISTICS OF A DENOMINATIONAL STATE. SOME REMARKS BASED ON THE ACCOMPLISHMENTS OF CONTEMPORARY CONSTITUTIONALISM}

\section{Sum mary}

An analysis of contemporary constitutions indicates that the number of denominational states is slowly decreasing. However, we also encounter opposite tendencies. The model of a denominational, or a religious state is primarily characteristic for Muslim countries of the Near and Middle East and for a number of Southeast Asian countries. In the last decades, the number of Christian states and secular ideological states has declined significantly. There is a stable group of states with Buddhism as a privileged religion. The religious constitutional norms of states of confession are generally characterised by a high degree of generality. Detailed provisions are seldom and denominational clauses are primarily included among the principles of the supreme constitution. Underlying the religious character of the state lies the rejection of the neutrality of the worldview. It is not possible, on the basis of

92 J. Szymanek, Konstytucjonalizacja idei państwa wyznaniowego, w: Państwo wyznaniowe..., s. 71.

${ }^{93}$ Por. R. Torfs, Stosunki państwo-Kościót wXXI wieku, „Europe Infos” 2000, nr 13, s. 6-7. 
the constitution alone, to reconstruct a detailed, universal model of a religious state. In the light of fundamental laws, the most common characteristics of religious states are: the negation of the neutrality of the state in worldviews, the acceptance of a particular religion as the official religion, the rejection of the equality of religious associations, the requirement of a head of state to follow the state religion or belief, and the state support for a given confession. The constitutions of most religious states formally provide for religious freedom. In the fundamental laws of some Muslim states, the guarantees for this freedom are, however, silent. The Western political culture fails the characteristics of an organisational unity of the state or the religious apparatus. The socio-political reality of contemporary religious states indicates that this model of statehood cannot be a priori regarded as contrary to the principles of democracy and human rights.

Keywords: religious/denominational state - the state-church relationship - contemporary constitutions - freedom of religion - Islam 